\title{
Comparison of the Effect of Scientific and Conventional Learning on the Creativity and Learning Outcomes of Physical Education Student
}

\author{
Wicaksono \\ Educational Technology, \\ Postgraduate Program \\ Universitas Negeri Medan, \\ Indonesia \\ wicak123456789@gmail.com
}

\author{
Albadi Sinulingga \\ Educational Technology, \\ Postgraduate Program \\ Universitas Negeri Medan, \\ Indonesia
}

\author{
Sabaruddin Yunis Bangun \\ Educational Technology, \\ Postgraduate Program \\ Universitas Negeri Medan, \\ Indonesia
}

\begin{abstract}
This study aims to determine and describe the Comparison of the Effects of Scientific and Conventional Learning on the Creativity and Learning Outcomes of High School Physical Education Students. This research is an experiment through a test instrument technique for learning outcomes and a questionnaire for creativity, with anava $2 \times 2$ research design. The number of samples was 71 people for the scientific learning group and 57 people for the conventional learning group and the sampling technique using cluster random sampling. Before conducting the analysis of variance (anava), first conduct the analysis requirements, namely the normality test and homogeneity test. Furthermore, the two-way Anava test was used at the $\alpha$ significance level of 0.05 and continued with the Scheffe test at the significance level $\alpha=0.05$. The results showed that there were differences in the influence of conventional learning and scientific learning on creativity and physical education learning outcomes and the interaction between the effects of conventional learning and scientific learning on creativity and physical education learning outcomes.
\end{abstract}

Keywords: Conventional Learning, Scientific Learning, Creativity, and Learning outcomes

\section{INTRODUCTION}

The progress and prosperity of a nation is very dependent on the quality of its Human Resources (HR). Naturally, improving the quality of human resources is a serious concern from every country including Indonesia. The quality of human resources certainly cannot be separated from the quality of education. How important this education has been conveyed by many circles and experts. Daoed Joesoef believes that education can not only encourage development but is also needed as a sacred goal of development (Kompas, 2006). Through education efforts, it is hoped that the quality of young people who are intelligent, creative and independent can be realized.

But in fact the creativity of students today is growing slowly and the use of learning media is lacking. This is because the education system is always dependent on educators. Sani (2013: 1) says that learning by teachers in Indonesia in general is still teacher-centered. This is due to inadequate understanding and learning paradigms that are not in accordance with the actions taken.
Seeing the reality that occurs in the field, so far the method used by educators in the learning process in class is only focused on the pattern of "Teacher Center" so that the active role of students is not optimal. Though it is clear that in the learning process, students must also play an active role so that what is the goal of learning can be absorbed by students to the fullest and later it is expected that learning outcomes will be achieved in accordance with what is expected by the teacher and students.

\section{METHOD}

This type of research uses a quantitative approach using an experimental design form with the design of this study is the 2 $\mathrm{X} 2$ desaign factor. In this design there are two groups chosen randomly, then given a pretest to find out the initial state whether there is a difference between the experimental group and the control group (Sugiono , 213: 113). Furthermore Margono (2014: 110) experimental research uses an experiment specifically designed to generate the data needed.

TABLE 1. RESEARCH DESIGN

\begin{tabular}{|c|c|c|}
\hline \multirow{2}{*}{ Impact (B) } & \multicolumn{2}{|c|}{ Learning Grup (A) } \\
\cline { 2 - 3 } & Conventional (A1) & Scientific (A2) \\
\hline Creativity (B1) & A1B1 & A2B1 \\
\hline Hasil Belajar (B2) & A1B2 & A2B2 \\
\hline
\end{tabular}

Information :

A1 : Conventional Learning Groups

A2 : Scientific Learning Group

B1 : Creativity

B2 : Learning Outcomes

A1B1 : Conventional learning with creativity

A1B2 : Conventional learning with

Physical Education learning outcomes

A2B1 : Scientific Learning with creativity 
A2B2 :Scientific Learning with the Learning Outcomes of the Pendjas

If Sig. $<0.05$ reject $\mathrm{H}_{0}$

If $\mathrm{Sig}$ value $>0.05$ accept $\mathrm{H}_{0}$

So the significance level of 0.05 can be concluded that there are different relationships or averages between grades based on school groups.

For the SMA Negeri 1 Kisaran group, creativity was obtained with an average of 156.61 and $S D=19,513$, Physical Education learning outcomes obtained an average learning result of 155.03 and $\mathrm{SD}=13.71$ with $\mathrm{n}=36$. Whereas for the SMA N 2 range creativity was obtained with an average of 158.27 and elementary school $=12.743$, Physical Education learning outcomes obtained an average of 169.36 and elementary school $=9,601$ with $n=33$. Furthermore, for the Tamansiswa Private High School group the range of creativity gained an average of 156.00 and elementary school $=12,558$, Physical Education learning outcomes obtained an average of 153.15 and elementary $=14.325$ with $n=27$. While for the Muhammadiyah Private High School group, creativity was obtained with an average of 159.53 and $\mathrm{SD}=13.725$. Physical Education learning outcomes obtained an average of 155.74 and $\mathrm{SD}=14.379$ with $\mathrm{n}=32$.

\section{DISCUSSION OF RESEARCH RESULTS}

Based on the findings made and described earlier, the discussion in this study can be explained as follows:

Differences in the Effects of the Application of Conventional Learning and Scientific Learning on Creativity and Physical Education Learning Outcomes

Based on the results of data analysis that has been done, it can be concluded that there is a significant difference between the application of conventional learning scientific learning to creativity and Physical Education learning outcomes, where the application of scientific learning is superior to conventional learning. This is in accordance with research conducted by Katimo (2013: 19) which results that "there is an influence on learning achievement and creativity of students who have high and low scientific attitudes. Through the explanation of the theory, it can be concluded that the application of conventional learning and scientific learning carried out can actually increase the creativity and learning outcomes of Physical Education students, where the application of scientific learning is better than the application of conventional learning to creativity and learning outcomes of Physical Education students.

\section{Interaction of Effect of Application of Conventional Learning and Scientific Learning on Creativity and Physical Learning Outcomes}

In accordance with the results of data analysis that has been done, that the findings in this study indicate that there is an interaction between the application of scientific learning with conventional learning on creativity and Physical
Education learning outcomes. Furthermore, it was found that Ho was rejected and Ha was accepted. It can be concluded that there is an interaction between the application of scientific learning and conventional learning on creativity and Physical Education learning outcomes. The results of the theory, it can be concluded that the application of conventional learning and scientific learning carried out can improve the creativity and learning outcomes of Physical Education students, where there is an interaction between the application of conventional learning and scientific learning. The interaction occurs because not the average number of each variable found in data processing.

\section{Advanced Test (Scheffe Test)}

Data processing carried out shows there is interaction, for that we need further testing. The further test carried out was the Scheffe test, because the number of samples for each group was not the same. The results of the Scheffe test show that: For school groups with the application of scientific learning, it was found that creativity and learning outcomes of Penjas Negeri 2 High School were superior compared to SMA $\mathrm{N} 1$ Kisaran. This is because in the learning process that involves the teacher more active and skilled when providing learning material, so students understand and understand more in completing assignments and the final outcome of learning. Furthermore, for school groups with the application of conventional learning, it was found that creativity and learning outcomes of the Physical Education Department of Muhammadiyah Kisaran High School were superior to Tamansiswa Kisaran Private High School. This is because in the learning process teachers are less creative in delivering subject matter as well as inadequate sports equipment and infrastructure support in accordance with the ratio of the number of students taught. Conclusion From the results of the hypothesis research and discussion of the results of the research it can be concluded that there are differences in the influence of the application of conventional learning and scientific learning on Physical Education and Physical Education learning outcomes. This shows that there are differences in the direct effect between conventional learning and scientific learning on Physical Education and Physical Education learning outcomes, where the application of scientific learning is higher than the application of conventional learning as a whole towards the creativity of students and Physical Education learning outcomes.

The interaction between the application of conventional learning and scientific learning to the creativity and learning outcomes of Physical Education. This shows that there is an interaction between the application of conventional learning and scientific learning on creativity and Physical Education learning outcomes.

\section{CONCLUSION}

From the results of the hypothesis research and discussion of the results of the research it can be concluded that there are differences in the influence of the application of conventional 
learning and scientific learning on Physical Education and Physical Education learning outcomes. This shows that there is a difference in the direct effect between conventional learning and scientific learning on Physical Education and Physical Education learning outcomes, where the application of scientific learning is higher than the application of conventional learning as a whole towards the creativity of students and Physical Education learning outcomes. The interaction between the application of conventional learning and scientific learning to the creativity and learning outcomes of Physical Education. This shows that there is an interaction between the application of conventional learning and scientific learning on creativity and Physical Education learning outcomes.

\section{REFERENCES}

[1] Daud Joesoef. 2006. He and I Seek the Truth. Jakarta: Kompas

[2] Ministry of National Education. 2003. State Budget to Succeed National Education and Build Quality Human Resources.

[3] Ministry of National Education. 2001. Large Indonesian Dictionary. Jakarta: Balai Pustaka.

[4] Director General of Higher Education Ministry of Education and Culture. 2012. Indonesian National Qualification Framework (KKNI)

[6] Fadillah.2014.Curriculum Implementation in Elementary and High School and High School Learning. Yogyakarta: Ar-Ruzz.

[7] Ishmael. 2006.Student Creativity on Waste Recycling Material Using the PPA Model. Lampung: FKIP

[8] Kasmadi and Nia Siti Sunariah. 2014. Modern Guide to Quantitative Research. Bandung. Alfabeta. Kompas. 1 May 2003.

[9] UNDP Human Development Report, p. 3 Kemendibud. 2014.

[10] Teacher's Book on Physical Education and Sport. Jakarta Margono. 2014. Educational Research Methodology.Jakarta: Rineka Copyright Publisher.

[11] Muhajirin. 2007. Physical Education Theory and Practice for Middle School Class VII. Jakarta: Erlangga

[12] Publisher. Article 3 of Law No. 20 of 2003. National Education System.

[13] Ridwan Abdullah Sani. 2014. Scientific Learning for the Implementation of the 2013 Jakarta Curriculum: PT Bumi Aksara.

[14] S. Margono. 2014. Educational Research Methodology. Jakarta: PT. Rineka Cipta Simorangkir.

[15] Frida Marta Argareta. 2017. Differences in the Mathematical Problem Solving Ability of Students Taught by Problem-Based Learning and Conventional Learning in SMA N 7 Padang 2017/2018 Academic Year.

[16] Sinulingga, Purnama. 2017. The Effect of Inquiry Training and Creativity Learning Models on Science Process Skills. Unimed

Postgraduate Physics Study Program. Siregar,

[17] Syofian. 2012. Parametric Statistics for Quantitative Research. Jakarta: PT. Earth Literacy.

[18] Slameto 2015. Learning and Factors That Influence It. Jakarta: PT Rineka Cipta.

[19] Sucipto. 2000. Soccer. Jakarta: Ministry of Education and Culture Director General of Higher Education

[20] Sudjana. 2017. Statistics Method. Bandung: Tarsito Sufianti Ika.dkk 2017. Effect of Scientific Approach Against Creative Thinking Skills of Students. Scientific Journal of Physical Education. Vol 5 No.2, 23384417.

[21] Sugiyono 2013. Educational Research Methods. Bandung: Alfabeta Publisher.

[22] Tough Choices on Tough Times, 2007,National Cender on Education and Economy.

[23] Unesco. 2000. Human Development (HDI). Political and Economic Risk Consultant (PERC) survey. Swedish World Economic Forum Data. 2000
[24] Wina Sanjaya. 2006. Learning Strategies.Jakarta: Kencana Prenada Media Group. 